\title{
Acute Gastroenteritis and Associated Bacterial Isolates from Domestic Water Sources in Ile-Ife, Nigeria
}

\section{Ojo Omoyemi Rebecca and Olotu Emmanuel Juwon*}

Department of Microbiology, Faculty of Science, Adekunle Ajasin University, Akungba Akoko, Ondo State, Nigeria

*Corresponding Author: Olotu Emmanuel Juwon, Department of Microbiology, Faculty of Science, Adekunle Ajasin University, Akungba Akoko, Ondo State, Nigeria.

Received: October 23, 2019; Published: November 07, 2019

DOI: $10.31080 /$ ASGIS.2019.02.0097

\begin{abstract}
This study determined the acute gastroenteritis of associated bacteria isolates from domestic water sources, as well as the antibiotic susceptibility pattern of bacteria from the domestic water sources from implicated hotspots in Ile-Ife. It also determined the physical and chemical parameters of water quality with respect to the identified hotspots, so as to identify possible contamination of the domestic water from the implicated areas, detect the extended spectrum beta lactamase (ESBLs) and the resistance genes of the bacteria isolates.

Water samples were collected from different drinking water sources. Samples were collected every week from different sources between January to April, 2016. Antibiotic susceptibility pattern of the isolates was conducted using standard protocols while, the detection of the ESBL gene (SHV) was done using PCR based techniques, the results were statistically analysed using Graphpad Prism 6.

Using conventional biochemical kits, the bacteria isolates were identified as Enterobacter spp., Serratia spp., Klebsiella spp., Shigella spp., Escherichia coli, Citrobacter spp., Yersinia spp., Proteus spp., Kluyvera spp., Aeromonas spp. Physicochemical analysis showed the mean values of $\mathrm{pH}$ in the range of $5.12 \pm 0.11$ to $7.30 \pm 0.43$ with Akarabata and Iremo 2 having the highest and least $\mathrm{pH}$ values respectively. High values were noticed in water quality parameters such as: total dissolved solid with range $55.50 \pm 16.24$ to $501.80 \pm 60.2 \mathrm{mg} / \mathrm{L}$ and electrical conductivity value range between $7.56 \pm 0.83$ to $151.09 \pm 23.16$. The highest Do $(1.467 \pm 0.133$ $\mathrm{mg} / \mathrm{L})$ and BOD $(0.596 \pm 0.120 \mathrm{mg} / \mathrm{L})$ values were observed in Iremo 5 and Iremo 1 respectively. Bacteriological evaluation of water samples from Ife East Local Government, showed heterotrophic plate count (HPC) ranged between $2.832 \pm 0.212$ and $4.076 \pm 0.093$ Log cfu/mL. Total coliform count (TCC) ranged between 19.60 \pm 5.144 and 758.60 \pm 359.8 MPN index/100mL. Water samples from Ife Central Local Government had Heterotrophic plate count ranged between $2.522 \pm 0.119$ and $4.044 \pm 0.060 \mathrm{Log} \mathrm{cfu} / \mathrm{mL}$. TCC ranged between $0.00 \pm 0.00$ and $861 \pm 466.0 \mathrm{MPN}$ index/100mL. Antibiotic susceptibility study showed $83.61 \%$ of the isolates were resistant to cefuroxime, (83.6\%) cefixime, (81.1\%) augmentin, (63.6\%) ceftazidime, (58.2\%) nitrofurantoin, (50.9\%) ofloxacin and $(38.2 \%)$ gentamicin. Nine $(8.1 \%)$ of the isolates subjected to phenotypic detection of ESBL genes showed the presence of these genes. SHV gene was detected in 5 (55.6\%) of the isolates.

The study concluded that acute gastroenteritis was endemic in the study area, with greater vulnerability in areas where clean water and proper sanitary conditions were inadequate.

Keywords: Antibiotic; Endemic; Gastroenteritis; Heterotrophic; Coliform; Resistant; Beta Lactamase
\end{abstract}

\section{Introduction}

Water is one of the indispensable natural resources useful for developmental purposes in both urban and rural areas. Despite this, most of the rural communities in the developing countries, especially Nigeria, lack access to potable water supply. They depend commonly on rivers, streams, wells, and ponds for daily water needs [1]. Most water resources accessible to households in rural areas are subjected to chemical and biological contaminations which may come from animals, septic tanks, storms water runoff [2].
Although water-related diseases have largely been eliminated in most developed nations, they remain a major concern in much of the developing world. The World Health Organization estimated in year 2013 that there are 1.7 billion cases of diarrhoea each year in addition to millions of other cases of illness associated with lack of access to clean water. Since many illnesses are undiagnosed and unreported, the true extent of these diarrhoea diseases is unknown. Diarrheal diseases have been reported to cause 1.5 million deaths in the year 2012 [3]. 
Diseases primarily transmitted through the faecal-oral route include diarrhoea, typhoid, cholera and infectious hepatitis. Diseases acquired through faecal-oral routes are associated with acute symptoms (with a probability of death). Transmission may occur through a variety of mechanisms, including consumption of contaminated water and food as well as through person to person contact [4].

Gastroenteritis refers to several conditions affecting the gastrointestinal system that exhibits watery or unformed stools and are usually caused by infections or intoxications with a biological agent [5]. It is an inflammation of the intestines that causes diarrhoea, abdominal cramps, nausea, loss of appetite, and other symptoms of digestive upset. In adults, the two most common causes of gastroenteritis are viral and bacterial infections. Diarrhoea is the second leading cause of preventable illness in children under age five [6,7].

Acute Gastroenteritis popularly known as infectious diarrhoea is the inflammation of the gastrointestinal tract that involves the stomach and small intestine which typically lasts less than two weeks [8]. Signs and symptoms include some combination of diarrhoea, vomiting, and abdominal pain [9]. Fever, lack of energy, and dehydration may also occur [10]. Acute gastroenteritis can be due to infections by viruses, bacteria, parasites, and fungi $[10,11]$.

\section{Justification of the study}

Acute gastroenteritis has been a public health problem in developing countries partly because of poor access to clean and safe water and inadequately treated sewage discharges. It has been reported that the presence of faecal leukocytes, frequent diarrhoea, and eating of crabs and shrimps are highly associated with bacterial gastroenteritis [12]. According to the WHO [13] the greatest risk associated with the ingestion of water is the microbial risk due to water contamination by sewage that contains enteric pathogens and viruses.

\section{Specific objectives of the Study are to}

- Determine the physical and chemical parameters of the water samples from the identified locations;

- Isolate and identify the bacterial strains from domestic water source sample;

- $\quad$ Determine antibiotic susceptibility profile of the isolates and

- Identify the acute gastroenteritis disease hotspots that could serve as reservoir for outbreaks in Ile-Ife.

\section{Materials and Methods \\ Ethical clearance}

Ethical clearance was obtained from Obafemi Awolowo University Teaching Hospital Complex (OAUTHC) Ethics Research Committee. Informed consent was obtained from parents whose children participated before data collection, patient's anonymity was maintained, data generated were confidential, and used only for the purpose of this research. Three hundred and seventy three (373) addresses of people who had acute gastroenteritis were obtained from the hospital's medical record of acute gastroenteritis case from the year 2008-2012 from whom informed consents were obtained.

\section{Study participants}

The study participants included the residents of the addresses obtained from the medical records of Obafemi Awolowo University Teaching Hospital complex, Ile-Ife, Osun State. Demographic data such as age, sex, type of sewer used, source of drinking water and symptoms observed during episodes of acute gastroenteritis and treatment method were obtained using questionnaires.

\section{Study area}

Ile-Ife, comprising Ife central and Ife East Local Government Area, Osun State, Nigeria constituted the study area. The Local Government Area (LGA) is located within latitude $7^{\circ} 31^{\prime}$ and $7^{\circ} 35^{\prime}$ North of equator and longitude $4^{\circ} 30^{\prime}$ and $4^{\circ} 35^{\prime}$ East of Greenwich meridian respectively. Ile-Ife city lies on the Southern flank of the western highlands of Nigeria consisting of 21 wards, with Ife central having 11 wards and Ife East with 10 wards. Generally, Ile-Ife is an undulating terrain mainly in form of plains and valleys. Three major rivers Ogbe, Ilode and Esinmirin, which are tributaries to Opa River drain are in the study area.

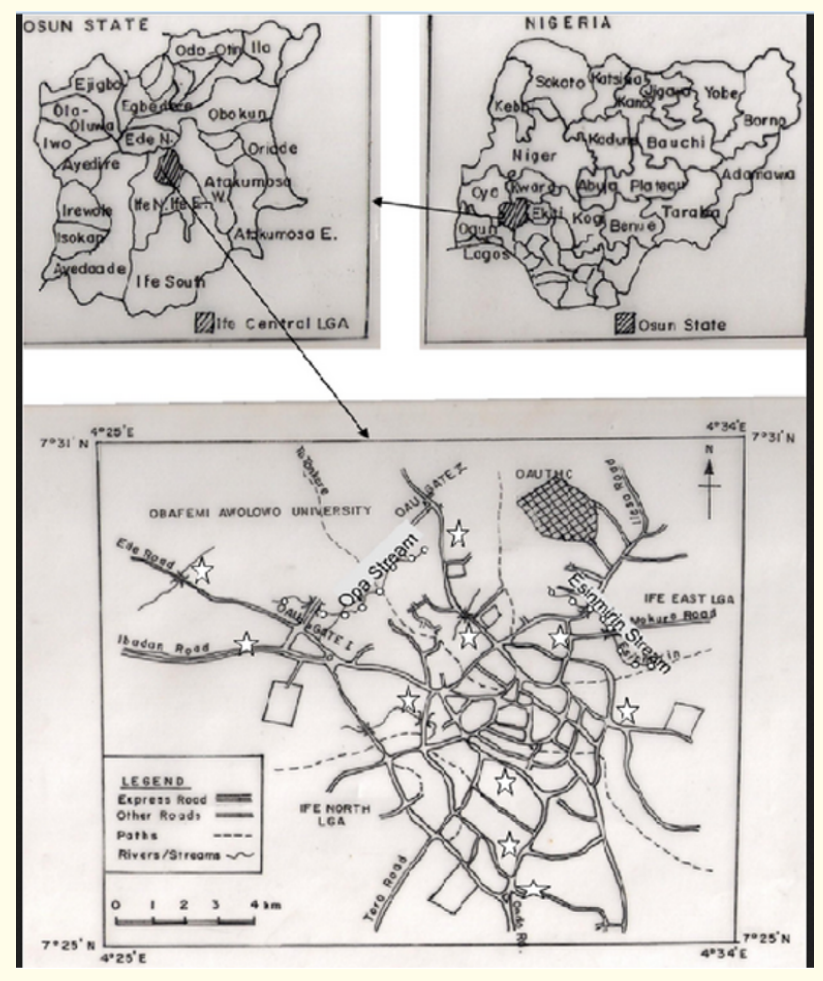

Figure 1: The Study Area, Ile-Ife.

Source: Osun State ministry of land and housing, 2018. 


\section{Preparation of media}

The media used includes nutrient agar, nutrient broth, MacConkey agar, MacConkey broth, eosin methylene blue agar, Mueller Hilton agar, sulphide indole motility (SIM) agar and triple sugar iron (TSI) agar. All the media used were prepared according to the manufacturer's instructions.

\section{Sample collection}

Drinking water samples were collected using purposive sampling technique from one hundred (100) different points from the residential address obtained from the medical records of Obafemi Awolowo University Teaching Hospital Complex (OAUTHC). Five (5) water samples were taken from each ward from a total of twenty wards which makes a total of one hundred (100) water samples that were collected between January 2016 and April 2016 (Dry season) using sterile universal bottles. Eighty four (84) water samples were collected from well water and sixteen (16) water samples were collected from tap water. Samples collected were transported to the Microbiology Laboratory and cultured within three hours of collection.

The following physicochemical parameter analysis was done for the water samples

Temperature, Ph, Total dissolved solid (TDS), Dissolved Oxygen (DO), Biological oxygen demand (BOD), Electrical conductivity.

\section{Microbiological analysis}

The microbiological quality of the drinking water was conducted using the multiple fermentation tube technique.

Confirmatory tests for faecal coliform (FC)

Sterile inoculating loop was used to pick a loopful from a positive presumptive tube which was streaked across the surface of the Eosin methylene blue agar. The petri dishes were then incubated at $44.5^{\circ} \mathrm{C}$ for $24 \mathrm{~h}$.

\section{Confirmatory test for total coliform (TC)}

Sterile inoculating loop was used to pick a loopful from a positive presumptive tube which was streaked across the surface of the sterilized MacConkey agar. The petri dishes were incubated in inverted position at $37^{\circ} \mathrm{C}$ for $24 \mathrm{~h}$.

\section{Heterotrophic plate count (HPC)}

One $\mathrm{mL}$ each of the samples was serially diluted up to 10-4. Aliquots $(0.1 \mathrm{~mL})$ of appropriately diluted samples were spread on Nutrient agar in duplicates. Plates were incubated at $37^{\circ} \mathrm{C}$ for $24 \mathrm{~h}$ in an inverted position for the growth of total bacteria. All colonies were counted as heterotrophic organisms.

\section{Identification of isolates}

The bacterial isolates were characterized by microscopic examination and identified by conventional biochemical tests. The cultures were examined for colony morphology, cell morphology, motility, gram stain and sugar fermentation tests. The isolated colonies were identified using Bergey's manual of determinative bacteriology.

\section{Biochemical tests}

The following biochemical tests were carried out to characterize and identify the isolates.

Catalase test, Motility test, Citrate utilization test, Methyl red Voges-Proskauer (MR-VP) test, Oxidase test, Indole test, Triple sugar iron agar (TSI) test

\section{Antibiotic susceptibility test}

The antibiotic susceptibility test was conducted by using disc diffusion method and interpreted according to Clinical Laboratory Standard Institute [14]. Mueller-Hinton Agar was prepared according to the manufacturer's instructions. The medium was allowed to cool and aseptically poured into sterile petri dishes and allowed to set. $18 \mathrm{~h}$ old nutrient broth culture of the isolates were standardized to match the $0.5 \mathrm{McFarland}$ in order to yield $1.5 \times 108 \mathrm{cfu} / \mathrm{ml}$ using a colorimeter. Mueller-Hinton agar plates were inoculated by spreading with sterile cotton-tipped applicator moistened and drained to remove excess inoculum load in the standardized suspension. The inoculated agar plates were allowed to dry for a few minutes at room temperature. The impregnated antibiotic discs of known concentrations: gentamicin $(10 \mu \mathrm{g})$, cefotaxime $(30 \mu \mathrm{g})$, cefuroxime $(30 \mu \mathrm{g})$, ceftazidime $(30 \mu \mathrm{g})$, cefixime $(5 \mu \mathrm{g})$, ofloxacin $(5 \mu \mathrm{g})$, augmentin $(10 \mu \mathrm{g})$, nitrofurantoin $(300 \mu \mathrm{g})$, ciprofloxacin $(5 \mu \mathrm{g})$, cefixime $(5 \mu \mathrm{g})$ (Abtek Biologicals, UK) were all carefully seeded on the inoculated Mueller-Hinton agar plates using sterile forceps. The plates were incubated in inverted position at 37oC for $18-24$ h. Thereafter, the diameters of the zones of inhibition were measured to the nearest millimetre and recorded. The results were recorded as resistant, intermediate and susceptible according to the approved guidelines of the Clinical Laboratory Standards Institute [14].

\section{Beta-Lactamase test}

Acidimetric agar plate method was adopted as described by Isenberg (2004). To $100 \mathrm{ml}$ of distilled water, $0.2 \mathrm{ml}$ of $0.5 \%$ phenol red solution was added and homogenized. Using $1 \% \mathrm{NaOH}$, the $\mathrm{pH}$ was adjusted to 9.0. The mixture was allowed to cool and thereafter, $100 \mathrm{mg}$ of penicillin $\mathrm{G}$ powder was added to yield a concentration of $5000 \mu / \mathrm{ml}$. Bacterial isolates were suspended in the penicillin phenol red test reagent dispensed in $100 \mu$ l volume in micro-titre wells. Change in colour from purple pink to yellow within 15 minutes was regarded as positive while absence of colour change within $15 \mathrm{~min}$ utes was taken as negative for the production of $\beta$-lactamase.

Phenotypic Detection of Extended Spectrum Beta-Lactamase (ESBL) in the isolates by double disk diffusion method

The double disk diffusion method (double disk synergy test) described by was used to detect ESBL production in the isolates. 
Pure isolates were adjusted to match the 0.5 Mc Farland standard using a colorimeter. The standardized isolates were spread onto a sterile Mueller-Hinton agar plate with sterile cotton tipped applicators and allowed to dry for $3 \mathrm{~min}$. A ceftazidime 30mg disc was placed on the left and a cefotaxime $30 \mathrm{mg}$ disc was placed on the right while an amoxicillin/clavulanic acid $20+10 \mathrm{mg}$ disc was placed at the centre of the plate. The discs were placed at $20 \mathrm{~mm}$ apart, centre to centre, the plate was incubated at $35^{\circ} \mathrm{C}$ for $24 \mathrm{~h}$, ESBL production was inferred when the zone of inhibition around the ceftazidime or cefotaxime disc was expanded by the clavulanate. The diameter of the zones of inhibition were measured to the nearest millimetre and recorded according to Clinical Laboratory Standards Institute [14].

\section{Extraction of chromosomal DNA from the isolates}

A loopful of culture from each isolates were streaked on sterile nutrient agar plates and incubated inverted at $37^{\circ} \mathrm{C}$ for $18-24 \mathrm{~h}$. Distinct colonies of bacteria were picked with sterile inoculating loop and the bacterial colonies were suspended in $200 \mu \mathrm{L}$ of sterile distilled water in appropriately labelled Eppendorf tubes. The bacterial suspension in the Eppendorf tubes were boiled at $100^{\circ} \mathrm{C}$ for $7 \mathrm{~min}$ in a water bath, cold shocked in ice for $2 \mathrm{~min}$ and then centrifuged at $10,000 \mathrm{rpm}$ for $45 \mathrm{~s}$, the supernatant containing DNA is then harvested for PCR or stored at $4^{\circ} \mathrm{C}$.

Polymerase Chain Reaction (PCR) amplification and detection of PCR products

Nine multiple antibiotic resistant (MAR) isolates were further screened for the selection of the BlaSHV resistant gene using PCR amplification technique. The selection of the isolates were based on $\beta$-lactamase production test.

Molecular detection of BlaSHV resistance gene in the isolates

The PCR reaction was set up in a PCR vial, after adding the master mix, the forward and reverse primers as shown in Table 4. Amplification reaction was carried out in a total reaction volume of $25 \mu \mathrm{L}$ of a PCR mixture. $25 \mu \mathrm{L}$ of master mix contained $4 \mu \mathrm{L}$ of $10 \mathrm{X}$ buffer, $0.5 \mu \mathrm{L} \mathrm{MgCl} 2,3 \mu \mathrm{L}$ dNTPs, and $0.2 \mu \mathrm{L}$ Taq polymerase.

The PCR vial was placed in PCR machine and it was subjected to initial denaturation at $94^{\circ} \mathrm{C}$ for $3 \mathrm{~min}$, followed by 30 cycles of denaturation at $94^{\circ} \mathrm{C}$ for $1 \mathrm{~min}$, annealing at $60^{\circ} \mathrm{C}$ for $1 \mathrm{~min}$ and extension at $72^{\circ} \mathrm{C}$ for $1 \mathrm{~min}$. A final extension procedure was carried out at $72^{\circ} \mathrm{C}$ for $5 \mathrm{~min}$. Gel electrophoresis was used to detect amplified DNA product. At the completion of the amplification, PCR products were resolved on $1 \%$ agarose gel prepared by dissolving $1 \mathrm{~g}$ of agarose powder in $100 \mathrm{~mL}$ of $1 \mathrm{X}$ Tris-borate-EDTA (TBE) buffer solution inside a clean conical flask. The $1 \%$ agarose solution was heated in a microwave oven for 2-3 min.

The gel was then allowed to cool to about $50^{\circ} \mathrm{C}$ after which 0.5 $\mu \mathrm{L}$ of ethidium bromide was added. It was allowed to cool further and poured into a gel tray sealed to form a mold. The gel plate was placed in an electrophoresis tank which contained $1 \mathrm{X}$ TBE solution. Five $\mu \mathrm{L}$ of amplicon was mixed with $5 \mu \mathrm{L}$ of Orange $\mathrm{G}$ (loading buffer). The mixture $10 \mu \mathrm{L}$ was loaded to the well of agarose gel electrophoresis. Power supply was adjusted to 100 volt for $25 \mathrm{~min}$ and gel was placed into the $1 \mathrm{X}$ TBE buffer in the tank.

For each run, a 100 base-pair molecular weight DNA standard (size marker) was used to detect the appropriate size for each PCR product. The DNA bands were then captured and visualized with a short wave ultraviolet trans-illuminator and photographed using gene gel bio-imaging system.

\section{Statistical analysis}

Data obtained were subjected to statistical analysis using Graphpad prism 6. Mean values and standard error of the mean were used to summarize the physicochemical and microbial quality of the water samples. Simple percentage was used to express the antibiotic susceptibility pattern of the isolates.

\begin{tabular}{|c|c|c|c|c|c|}
\hline $\begin{array}{c}\text { ESBL } \\
\text { Primer }\end{array}$ & $\begin{array}{c}\text { Sequence } \\
\mathbf{5}^{\mathbf{1}-\mathbf{3}^{\mathbf{1}}}\end{array}$ & Gene & $\begin{array}{c}\text { Product } \\
\text { Size (bp) }\end{array}$ & $\begin{array}{c}\text { Annealing } \\
\text { Tempera- } \\
\text { ture }\end{array}$ & Reference \\
\hline SHV F & $\begin{array}{c}\text { AGGATT- } \\
\text { GACT- } \\
\text { GCCTTTTTG }\end{array}$ & $\begin{array}{c}\text { bla- } \\
\text { SHV }\end{array}$ & 393 & 60 & $\begin{array}{c}\text { Maynard } \\
\text { et al., 2003 }\end{array}$ \\
\hline
\end{tabular}

Table 1: Primer used for the Amplification of the Gene.

Socio-economic and demographic characteristics of the respondents

The data was collected from each patient's case note. The data obtained showed that children under the age of five had the highest percentage of occurrence (79.6\%), followed by 21 and above $(12.3 \%)$, with teenagers (11-20years) having the least percentage $(4.3 \%)$.

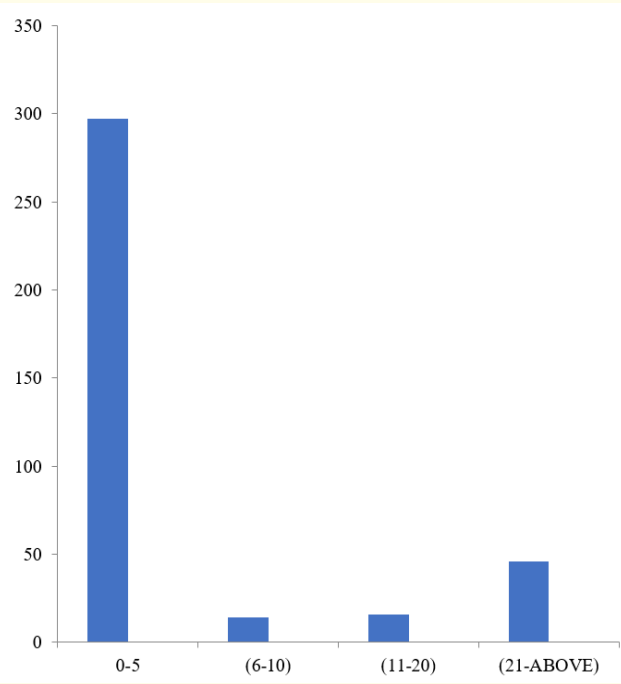

Figure 2: Age Distribution of Patients Affected with Acute Gastroenteritis from 2008-2012. 


\section{Results}

Physicochemical Analysis of Samples

Physicochemical analysis of water samples collected from Ife East Local Government

The overall mean values \pm standard error of the mean using different physicochemical parameters on analysed water samples collected from Ife East are presented on Table 2. The acidity and alkalinity $(\mathrm{pH})$ level of samples ranged between $5.52 \pm 0.092$ and $6.06 \pm 0.108$. The highest $\mathrm{pH}$ mean \pm standard error of the mean value was observed in Modekeke 2 while the lowest $\mathrm{pH}$ value was observed in Moore ward. Temperature ranged between $26.60 \pm$ 0.400 and $29.60 \pm 0.400^{\circ} \mathrm{C}$. The highest temperature value was observed in Modakeke 1 and the lowest in Ilode 2. Total dissolved solids ranged between $42.20 \pm 4.21$ and $233.80 \pm 38.7 \mathrm{mg} / \mathrm{L}$. High electrical conductivity values were evident in the analysed water samples with Modakeke 2 having the highest value of $528 \pm 92.32$. The mean \pm standard error of the mean value ranges for other parameters are; $0.400 \pm 0.00$ to $4.80 \pm 0.0 \mathrm{mg} / \mathrm{L}$ for dissolved oxygen and $0.093 \pm 0.013$ to $0.400 \pm 0.00 \mathrm{mg} / \mathrm{L}$ for dissolved oxygen.

Physicochemical analysis of water samples collected from Ife Central Local Government

Table 4 shows mean values of physicochemical parameters of analysed water samples collected from Ife Central Local Government Area. The acidity and alkalinity $(\mathrm{pH})$ mean \pm standard error of the mean value was in the range of $5.12 \pm 0.11$ to $7.30 \pm 0.43$ with Akarabata and Iremo 2 having the highest and least $\mathrm{pH}$ value respectively. Temperature mean \pm standard error of the mean value ranges between $26.40 \pm 0.245$ to $31.00 \pm 0.775^{\circ} \mathrm{C}$. The highest temperature mean \pm standard error of the mean value was observed in Ilare 2 while the least was observed in Iremo 4. High mean \pm standard error of the mean values were noticed in parameters such as; Total dissolved solid with a mean \pm standard error of the mean range $55.50 \pm 16.24$ to $501.80 \pm 60.2 \mathrm{mg} / \mathrm{L}$ and Electrical conductivity value range between $7.56 \pm 0.83$ to $151.09 \pm 23.16 \mu \mathrm{s}$. The highest DO $(1.467 \pm 0.133)$ and BOD $(0.596 \pm 0.120)$ mean \pm standard error of the mean values were observed in Iremo 5 and Iremo 1 respectively.

\section{Bacteriological quality of water samples}

Using parameters required to monitor/evaluate the quality of water, the general bacteriological quality of the water samples were analysed and compared with national and international standards.

Bacteriological analysis of samples collected from Ife East Local Governments in Osun State

The mean \pm standard error of the mean bacteriological counts of samples collected from Ife East Local Government are presented in Table 3. Heterotrophic Plate Count (HPC) ranged between $2.832 \pm$ 0.212 and $4.076 \pm 0.093 \mathrm{Log} \mathrm{cfu} / \mathrm{mL}$. Modakeke 2 had mean \pm standard error of the mean Total Coliform Count (TC) ranged between $19.60 \pm 5.144$ and $758.60 \pm 359.8$.

Bacteriological analysis of samples collected from Ife Central Local Governments in Osun State

Heterotrophic Plate Count mean \pm standard error of the mean ranged between $2.522 \pm 0.119$ and $4.044 \pm 0.060$. The highest and lowest HPC value were observed in Ilare 1 and Moore/ojaja ward respectively. TC ranged between $0.00 \pm 0.00$ and $861 \pm 466.0$.

\begin{tabular}{|c|c|c|c|c|c|c|c|c|c|c|}
\hline Parameters & $\begin{array}{c}\text { Modakeke } \\
1 \\
\end{array}$ & $\begin{array}{c}\text { Modakeke } \\
2 \\
\end{array}$ & $\begin{array}{c}\text { Modakeke } \\
3 \\
\end{array}$ & $\begin{array}{c}\text { Okerewe } \\
1 \\
\end{array}$ & $\begin{array}{c}\text { Okerewe } \\
2 \\
\end{array}$ & \begin{tabular}{|c|} 
Okerewe \\
3 \\
\end{tabular} & Ilode 1 & Ilode 2 & Moore & Yekemi \\
\hline $\mathrm{pH}$ & $\begin{array}{l}5.94 \pm \\
0.075 \\
\end{array}$ & $\begin{array}{r}6.06 \pm \\
0.108 \\
\end{array}$ & $\begin{array}{l}5.96 \pm \\
0.051 \\
\end{array}$ & $\begin{array}{l}5.94 \pm \\
0.136\end{array}$ & $\begin{array}{l}6.00 \pm \\
0.105 \\
\end{array}$ & $\begin{array}{l}6.04 \pm \\
0.103 \\
\end{array}$ & $\begin{array}{l}6.08 \pm \\
0.139 \\
\end{array}$ & $\begin{array}{l}6.06 \pm \\
0.144 \\
\end{array}$ & 0.092 & $\begin{array}{l}6.04 \pm \\
0.103 \\
\end{array}$ \\
\hline $\begin{array}{l}\text { Temperature } \\
\left({ }^{\circ} \mathrm{C}\right) \\
\end{array}$ & $\begin{array}{c}29.60 \pm \\
0.400\end{array}$ & $\begin{array}{c}28.60 \pm \\
0.510\end{array}$ & $\begin{array}{c}29.00 \pm \\
0.707\end{array}$ & $\begin{array}{c}28.00 \pm \\
0.316\end{array}$ & $\begin{array}{c}28.00 \pm \\
0.447\end{array}$ & $\begin{array}{c}28.10 \pm \\
0.400\end{array}$ & $\begin{array}{c}28.80 \pm \\
0.860\end{array}$ & $\begin{array}{c}26.60 \pm \\
0.400\end{array}$ & $\begin{array}{c}28.00 \pm \\
0.837\end{array}$ & $\begin{array}{c}28.00 \pm \\
0.447\end{array}$ \\
\hline TDS (mg/L) & $\begin{array}{c}42.20 \pm \\
4.21\end{array}$ & $\begin{array}{c}233.30 \pm \\
38.7\end{array}$ & $\begin{array}{c}50.40 \pm \\
10.59\end{array}$ & $\begin{array}{c}94.10 \pm \\
15.67\end{array}$ & $\begin{array}{c}61.80 \pm \\
16.79\end{array}$ & $\begin{array}{c}123.20 \pm \\
48.05\end{array}$ & $\begin{array}{c}216.30 \pm \\
65.42\end{array}$ & $\begin{array}{c}133.80 \pm \\
43.54\end{array}$ & $\begin{array}{c}89.30 \pm \\
8.70\end{array}$ & $\begin{array}{c}123.50 \pm \\
47.98\end{array}$ \\
\hline EC $(1$ & $\begin{array}{c}114.20 \pm \\
19.85\end{array}$ & $\begin{array}{c}528.0 \pm \\
92.32 \\
\end{array}$ & $\begin{array}{c}107.0 \pm \\
22.55 \\
\end{array}$ & $\begin{array}{c}206.1 \pm \\
36.70 \\
\end{array}$ & $\begin{array}{c}134.40 \pm \\
36.26\end{array}$ & $\begin{array}{c}258.3 \pm \\
100.84 \\
\end{array}$ & $\begin{array}{l}477.0 \pm \\
148.65 \\
\end{array}$ & $\begin{array}{c}286.30 \pm \\
94.07 \\
\end{array}$ & $\begin{array}{c}192.3 \pm \\
19.52 \\
\end{array}$ & $\begin{array}{l}258.4 \pm \\
100.96 \\
\end{array}$ \\
\hline $\mathrm{DO}(\mathrm{n}$ & $\begin{array}{c}0.400 \pm \\
0.00 \\
\end{array}$ & $0.800 \pm 0.00$ & $\begin{array}{c}0.800 \pm \\
0.00 \\
\end{array}$ & $\begin{array}{c}0.933 \pm \\
0.133 \\
\end{array}$ & $\begin{array}{c}1.067 \pm \\
0.133 \\
\end{array}$ & $\begin{array}{c}0.400 \pm \\
0.00 \\
\end{array}$ & $\begin{array}{c}4.80 \pm \\
0.00\end{array}$ & $\begin{array}{c}4.00 \pm \\
0.00 \\
\end{array}$ & $\begin{array}{c}1.467 \pm \\
0.133\end{array}$ & $\begin{array}{c}0.293 \pm \\
0.133 \\
\end{array}$ \\
\hline BOI & $\begin{array}{l}0.36 \pm \\
0.040\end{array}$ & $2 \pm 0$. & $\begin{array}{l}0.20 \pm \\
0.046\end{array}$ & $\begin{array}{c}0.20 \pm \\
0.00\end{array}$ & $\begin{array}{c}0.16 \pm \\
0.00\end{array}$ & $\begin{array}{c}0.40 \pm \\
0.00\end{array}$ & $\begin{array}{c}0.373 \pm \\
0.0 .03\end{array}$ & $\begin{array}{c}0.227 \pm \\
0.035 \\
\end{array}$ & $\begin{array}{c}0.093 \pm \\
0.013\end{array}$ & $\begin{array}{c}0.267 \pm \\
0.067 \\
\end{array}$ \\
\hline
\end{tabular}

Table 2: Mean \pm Standard Error of the Mean Values of Physico-chemical Parameters of Samples Collected from Ife East Local Governments in Osun State.

Values represent the mean of household samples \pm standard error 


\begin{tabular}{|c|c|c|c|c|c|c|c|c|c|c|}
\hline Parameters & $\begin{array}{c}\text { Modakeke } \\
1 \\
\end{array}$ & \begin{tabular}{|c|} 
Modakeke \\
2 \\
\end{tabular} & $\begin{array}{c}\text { Modakeke } \\
3 \\
\end{array}$ & \begin{tabular}{|c|} 
Okerewe \\
1 \\
\end{tabular} & $\begin{array}{c}\text { Okerewe } \\
2 \\
\end{array}$ & \begin{tabular}{|c|} 
Okerewe \\
$\mathbf{3}$ \\
\end{tabular} & Ilode 1 & Ilode 2 & Moore & Yekemi \\
\hline $\mathrm{HPC}\left(\log _{10} \mathrm{cfu} / \mathrm{mL}\right)$ & $\begin{array}{c}3.269 \pm \\
0.160\end{array}$ & $\begin{array}{c}4.076 \pm \\
0.093\end{array}$ & $\begin{array}{c}2.907 \pm \\
0.174\end{array}$ & $\begin{array}{c}3.221 \pm \\
0.183\end{array}$ & $\begin{array}{c}2.832 \pm \\
0.212\end{array}$ & $\begin{array}{c}3.237 \pm \\
0.052\end{array}$ & $\begin{array}{c}3.000 \pm \\
0.185\end{array}$ & $\begin{array}{c}3.009 \pm \\
0.046\end{array}$ & $\begin{array}{c}2.870 \pm \\
0.234\end{array}$ & $\begin{array}{c}3.329 \pm \\
0.032\end{array}$ \\
\hline $\begin{array}{l}\text { TCC(MPN } \\
\text { Index/100mL) }\end{array}$ & $\begin{array}{c}758.60 \pm \\
359.8\end{array}$ & $\begin{array}{c}537.0 \pm \\
374.0\end{array}$ & $\begin{array}{c}425.4 \pm \\
393.8\end{array}$ & $\begin{array}{c}22.80 \pm \\
3.707\end{array}$ & $\begin{array}{c}20.400 \pm \\
4.654\end{array}$ & $\begin{array}{c}19.60 \pm \\
5.144\end{array}$ & $\begin{array}{c}25.00 \pm \\
1.844\end{array}$ & $\begin{array}{c}26.40 \pm \\
1.600 \\
\end{array}$ & $\begin{array}{c}196.0 \pm \\
107.8\end{array}$ & $\begin{array}{c}22.600 \pm \\
6.933\end{array}$ \\
\hline
\end{tabular}

Table 3: Mean \pm Standard Error of the Mean Values of Bacteriological Parameters of Samples

Collected from Ife East Local Governments in Osun State.

Values represent the mean of household samples \pm standard error.

\begin{tabular}{|c|c|c|c|c|c|c|c|c|c|c|}
\hline Parameters & Akarabata & Ilare 1 & Ilare 2 & Ilare 3 & Iremo 1 & Iremo 2 & Iremo 3 & Iremo 4 & Iremo 5 & Moore/ojaja \\
\hline $\mathrm{pH}$ & $\begin{array}{l}7.30 \pm \\
0.430\end{array}$ & $\begin{array}{l}5.70 \pm \\
0.084\end{array}$ & $\begin{array}{l}6.18 \pm \\
0.395\end{array}$ & $\begin{array}{l}5.82 \pm \\
0.066\end{array}$ & $\begin{array}{l}6.04 \pm \\
0.068\end{array}$ & $\begin{array}{l}5.12 \pm \\
0.111\end{array}$ & $\begin{array}{l}5.78 \pm \\
0.265\end{array}$ & $\begin{array}{l}6.18 \pm \\
0.395\end{array}$ & $\begin{array}{l}5.90 \pm \\
0.145\end{array}$ & $7.24 \pm 0.367$ \\
\hline Temperature $\left({ }^{\circ} \mathrm{C}\right)$ & $\begin{array}{c}28.00 \pm \\
0.775\end{array}$ & $\begin{array}{c}29.00 \pm \\
0.316\end{array}$ & $\begin{array}{c}31.00 \pm \\
0.775\end{array}$ & $\begin{array}{c}28.00 \pm \\
0.800\end{array}$ & $\begin{array}{c}26.500 \pm \\
0.224\end{array}$ & $\begin{array}{c}27.00 \pm \\
0.316\end{array}$ & $\begin{array}{c}29.20 \pm \\
0.583\end{array}$ & $\begin{array}{c}26.40 \pm \\
0.245\end{array}$ & $\begin{array}{c}26.80 \pm \\
0.583\end{array}$ & $28.80 \pm 0.80$ \\
\hline TDS (mg/L) & $\begin{array}{c}91.40 \pm \\
1.15\end{array}$ & $\begin{array}{c}88.10 \pm \\
4.85\end{array}$ & $\begin{array}{c}182.9 \pm \\
29.54\end{array}$ & $\begin{array}{c}104.90 \pm \\
33.48\end{array}$ & $\begin{array}{c}55.50 \pm \\
16.24\end{array}$ & $\begin{array}{c}273.40 \pm \\
11.72\end{array}$ & $\begin{array}{c}408.40 \pm \\
61.66\end{array}$ & $\begin{array}{c}418.80 \pm \\
29.14\end{array}$ & $\begin{array}{c}501.80 \pm \\
60.2\end{array}$ & $95.00 \pm 3.08$ \\
\hline $\mathrm{EC}(\mu \mathrm{s})$ & $\begin{array}{c}207.30 \pm \\
1.99\end{array}$ & $\begin{array}{c}195.7 \pm \\
9.79\end{array}$ & $\begin{array}{c}405.60 \pm \\
68.59\end{array}$ & $\begin{array}{c}228.6 \pm \\
75.92\end{array}$ & $\begin{array}{c}116.30 \pm \\
32.53\end{array}$ & $\begin{array}{c}585.20 \pm \\
24.97\end{array}$ & $\begin{array}{l}920.6 \pm \\
151.67\end{array}$ & $\begin{array}{c}955.40 \pm \\
78.63\end{array}$ & $\begin{array}{c}1116.4 \pm \\
135.4\end{array}$ & $214.20 \pm 5.34$ \\
\hline $\mathrm{DO}(\mathrm{mg} / \mathrm{L})$ & $\begin{array}{c}0.773 \pm \\
0.027 \\
\end{array}$ & $\begin{array}{c}0.666 \pm \\
0.113\end{array}$ & $\begin{array}{c}4.533 \pm \\
0.304\end{array}$ & $\begin{array}{c}0.933 \pm \\
0.133\end{array}$ & $\begin{array}{c}1.067 \pm \\
0.133\end{array}$ & $\begin{array}{c}0.848 \pm \\
0.069\end{array}$ & $\begin{array}{c}1.307 \pm \\
0.098\end{array}$ & $\begin{array}{c}0.631 \pm \\
0.101\end{array}$ & $\begin{array}{c}1.467 \pm \\
0.133\end{array}$ & $0.293 \pm 0.133$ \\
\hline $\mathrm{BOD}(\mathrm{mg} / \mathrm{L})$ & $\begin{array}{l}0.36 \pm \\
0.040\end{array}$ & $\begin{array}{l}0.12 \pm \\
0.083\end{array}$ & $\begin{array}{c}0.149 \pm \\
0.012\end{array}$ & $\begin{array}{c}0.20 \pm \\
0.00\end{array}$ & $\begin{array}{c}0.596 \pm \\
0.120\end{array}$ & $\begin{array}{c}0.259 \pm \\
0.037\end{array}$ & $\begin{array}{c}0.373 \pm \\
0.0 .03\end{array}$ & $\begin{array}{c}0.527 \pm \\
0.044\end{array}$ & $\begin{array}{c}0.424 \pm \\
0.141\end{array}$ & $0.267 \pm 0.067$ \\
\hline
\end{tabular}

Table 4: Mean \pm Standard Error of the Mean Values of Physico-chemical Parameters of

Samples Collected from Ife Central Local Governments in Osun State.

Values represent the mean of household samples \pm standard error.

\begin{tabular}{|l|c|c|c|c|c|c|c|c|c|c|}
\hline \multicolumn{1}{|c|}{ Parameters } & Akarabata & Ilare 1 & Ilare 2 & Ilare 3 & Iremo 1 & Iremo 2 & Iremo 3 & Iremo 4 & Iremo 5 & Moore/ojaja \\
\hline HPC $\left(\mathrm{Log}_{10} \mathrm{cfu} / \mathrm{mL}\right)$ & $2.791 \pm$ & $4.044 \pm$ & $3.742 \pm$ & $3.743 \pm$ & $3.271 \pm$ & $3.099 \pm$ & $3.870 \pm$ & $3.781 \pm$ & $3.502 \pm$ & $2.522 \pm 0.119$ \\
& 0.108 & 0.060 & 0.245 & 0.297 & 0.031 & 0.133 & 0.234 & 0.173 & 0.208 & \\
\hline TCC $(\mathrm{MPN}$ & $53.00 \pm$ & $5.800 \pm$ & $834 \pm$ & $861 \pm$ & $0.00 \pm$ & $45.95 \pm$ & $23.75 \pm$ & $21.00 \pm$ & $296.6 \pm$ & $16.20 \pm 5.97$ \\
Index/100mL) & 46.8 & 1.828 & 329.9 & 466.0 & 0.00 & 8.14 & 2.98 & 2.074 & 100 & \\
\hline
\end{tabular}

Table 5: Mean \pm Standard Error of the Mean Values of Bacteriological Parameters of samples collected from Ife Central Local Governments in Osun State.

Values represent the mean of household samples \pm standard error.

Frequency of bacteria isolates from samples

One hundred bacteria isolates were obtained altogether from soil and water samples. Thirty eight (38) bacteria were isolated from the soil samples and sixty two (62) bacteria were isolated from the water samples. Enterobacter spp. represent the highest number of organisms isolated from this study while Kluvyera spp. was the least organism isolated.

\section{Antibiotics susceptibility profile of the isolates}

The results of the antibiotics susceptibility test showed resistance to cefuroxime 84 (83.6\%), cefixime 84 (83.6\%), augmentin 75 (81.1\%), ceftazidime 63 (63.6\%), nitrofurantoin 61 (58.2\%), ofloxacin $41(50.9 \%)$ and gentamicin $35(38.2 \%)$ in the isolates.
Fourteen of the isolates (27.3\%) and thirtyfive (30.9\%) were resistant to ciprofloxacin and gentamicin respectively. Enterobacter spp had the highest resistance occurring percentage (14\%) followed by Shigella spp. (13\%), with Kluyvera spp having the lowest percentage $(2 \%)$.

\section{Beta-Lactamase production test}

The results of the beta-lactamase test showed that ten (10) out of the one hundred isolates produced bright yellow colour in the tubes showing resistance strains. Four Enterobacter spp, two Shigella spp, two Klebsiella spp, Citrobacter spp and Serratia spp produced bright yellow colour in the phenol red tubes. 


\section{Phenotypic detection of ESBL in the isolates}

Nine (8.1\%) of the isolates subjected to phenotypic detection of ESBL were positive to the test. Three Enterobacter spp., two Shigella spp., two Klebsiella spp., Citrobacter spp. and Serratia spp. were found to produce ESBL phenotypically.

Genotypic detection of ESBL gene in the isolates

The molecular characterization of the ESBL resistance gene from the 9 bacterial isolates which was done using PCR technique. A total of $5(55.6 \%)$ isolates which includes two Enterobacter spp, Shigella spp, Citrobacter spp and Serratia spp showed detectable SHV genes in the bacterial isolates as shown in plate 1 .

\section{Prediction for likely hotspots of acute gastroenteritis in Ile-Ife}

The study revealed AGE is expected to increase in strategic wards and its occurrence is expected to be highest in Moore, Moore/Ojaja and Modakeke 2 in the near future if exposure rates remain the same in the study area as shown in Figure. This is because these wards has the highest number of likely occurrence with Moore ward having the highest value.

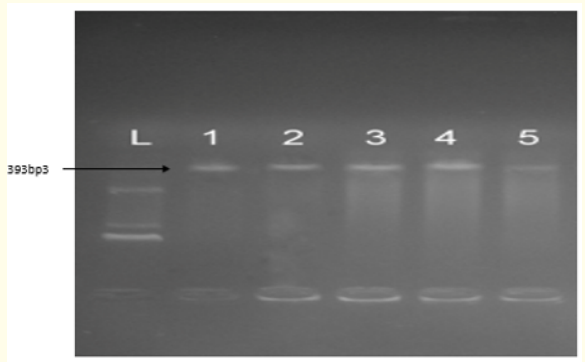

bla-SHV gene (393 bp): Isolate 01 to 5: Lane M: $100 \mathrm{bp}$ molecular weight marker; lanes 1 to 5 bacterial isolates. $\mathrm{L}=100 \mathrm{bp}$ ladder, 1 = MW42a, 2 = M76b, 3= M76c, 4 = EW34a, 5 = ES14 (1).

\section{Plate 1: Molecular Detection of bla-SHV Gene} in Bacterial Isolates.

\section{Discussion}

This study analysed the acute gastroenteritis disease hotspots that could serve as reservoir for future outbreaks. The study showed that Ilare1 (55), Modakeke 2 (50) and Moore (38) had the highest reported cases probably as a result of environmental and behavioural factors. From the survey of the area using questionnaires, it was seen that most part of the area has dirty environment which can aid occurrence of acute gastroenteritis. It can also be caused by the low level of income of the area and low level of education in the areas. The wards with high number of cases are within Ife East Local Government except Ilare 1. Environmental pollution, inadequate supply of water and sewage disposal systems are identified as important factors that increases vulnerability to acute gastroenteritis [15].
Higher occurrence of acute gastroenteritis among children was observed in the case notes of the patients and this may be linked to high susceptibility of children to infections due to their low immunity. This is in agreement with the work done by Oguntoke., et al. (2009) who worked on the Association of water-borne diseases morbidity pattern and water quality in parts of Ibadan.

Total dissolved solid and Electrical conductivity results revealed that values are within the range approved for domestic use except for Iremo 5. This is in agreement with the findings reported by Oluyemi., et al. [16] in a study conducted on physico-chemical properties and heavy metal content of water sources in Ife North Local Government Area.

The mean microbial counts of all parameters showed that virtually all analysed samples have counts exceeding WHO guideline for potable water. The considerably high microbial count for all parameters indicates that almost all analysed samples are unfit for domestic use without processing [17].

The high coliform count obtained in the samples is an indication that the water sources are faecally contaminated [18]. None of the water samples complies with EPA standard for coliform in water. This is in agreement with the study carried out by Shittu., et al. [19] on groundwater and streams used for drinking purposes in Abeokuta. According to EPA standard, every water sample that has coliform must be analysed for either faecal coliforms or E. coli [18] with a view to ascertaining contamination with human or animal waste and possibly pathogenic bacteria.

The detection of pathogenic organisms in some of the samples is a cause for concern as regards waterborne epidemics in the study area. On the basis of biochemical tests, the most prevalent organism in the present study were identified as Shigella spp., Serratia spp., Aeromonas spp., E. coli and Enterobacter spp. The presence of Vibro, Shigella, Enterobacter, E. coli and Salmonella species and other bacteria does not only make the water unsuitable for human consumption, but also poses serious health concerns [13]. The presence of the indicator bacteria such as Escherichia coli, Enterobacter species is undesirable in drinking water and signifies the faecal contamination of the water body and also the presence of other enteric pathogens. Similar studies carried out by Adejuwon and Adelakun [20] in bacteriological analysis of surface water in Ewekoro Local Government Area of Ogun State, Nigeria, reported the presence of these bacteria in drinking water sources and attributed it to indiscriminate human and animal defecation and general poor sanitation.

The relatively high level of resistance to antimicrobial agents especially the third generation cephalosporins; ceftazidime or cefotaxime could suggest a possible misuse or abuse of antibiot- 
ics in the environment [21]. The high rate of antibiotic-resistant bacteria from the samples has an ecological and public health implication which could become a problem associated with transfer of resistance determinants to other human pathogenic bacteria. Ten $(10 \%)$ out of the bacterial isolates produced beta-lactamase phenotypically while, nine (8.1\%) of the one hundred isolates were identified as ESBL-producing strains and showed high levels of resistance the tested antibiotics. Of these nine isolates, 33.3\% were Enterobacter spp, 22.2\% were Shigella and Klebsiella spp and $11.1 \%$ were Citrobacter and Serratia spp.

The results of the test for ESBLs production showed the ability to produce ESBLs among the isolates. Nine (8.1\%) of the isolates were identified as ESBL-producing strains. Of the nine isolates, $33.3 \%$ were Enterobacter spp, 22.2\% were Shigella and Klebsiella spp and $11.1 \%$ were Citrobacter and Serratia spp. Following the screening of the isolates for ESBL genes using PCR, SHV gene was detected in 5 (55.6\%). These findings suggest that this environmental isolate pose a serious threat to the people in the community and this conforms to other studies [22].

The study revealed AGE is expected to increase in certain wards and AGE occurrence is expected to be high in Moore, Moore/Ojaja and Modakeke 2 in the near future in the study area. The study suggests accurate forecasting and risk assessment will be an important first step in mitigating threats to human populations. Harrigan., et al. [23] in a study conducted in United States of America identified current and future hotspots of West Nile virus where mitigation efforts should be focused and presents an important new approach for monitoring vector-borne diseases.

\section{Conclusion}

This study focused on the acute gastroenteritis and associated bacterial isolates from domestic water sources in Ile-Ife, it also reveals that water from these study area is unsafe for drinking and domestic purposes. Results of antibiotic resistance indicated high level of resistance and emphasize the importance of constant surveillance of isolates to determine the prevalence of antibiotic resistant genes.

\section{Recommendations}

1. In view of the high level of multiple antibiotic resistances shown by organisms in this study, regulations should be enforced to govern the handling and sale of antibiotics to avoid self-medication.

2. Enlightenment of the public as regards personal hygiene of individuals, handling of foods, water and the environment is highly recommended.

3. Government should give priority to the supply of potable water to every home in order to reduce the occurrence of acute gastroenteritis and other water-borne disease that can be traced to lack of access to potable water consumption.
4. Continuous surveillance especially into the hotspot areas generated from this study to curb or stop future outbreaks.

\section{Bibliography}

1. World Health Organisation. Progress on Sanitation and Drinking water, 2015 update and MDG Assessment (2015).

2. Sawant RS., et al. "Water Pollution Status of Hiranyakeshi River from India". Global Journal of Science Frontier Research Environment and Earth Science 13 (2013): 10.

3. World health Organisation. "Burden of disease and cost-effectiveness estimates". World Health Organization (2014).

4. João PS. "Water Microbiology: Bacterial Pathogens and Water". International Journal of Environmental Research and Public health 7 (2010): 3657-3703.

5. Gilbert GL. "Improving foodborne disease surveillance in NSW". Public Health Bull Organization 19 (2008): 1-2.

6. Black RE., et al. "Global, regional, and national causes of child mortality in 2000-2013, with projections to inform post2015 priorities: an updated systematic analysis". The Lancet 385(2010): 430-440.

7. Wardlaw T., et al. "Diarrhoea: why children are still dying and what can be done". The Lancet 37 (2010): 2-8.

8. Schlossberg D. Clinical Infectious Disease. 2nd ed. (2015): 334

9. Singh A. "Pediatric Emergency Medicine Practice Acute Gastroenteritis- An Update". Emergency Medicine Practice 7 (2010): 76-88.

10. Ciccarelli S., et al. "Management strategies in the treatment of neonatal and paediatric gastroenteritis". Journal of Infection and drug resistance 6 (2013): 133-161.

11. Helms A and Richard E. Textbook of therapeutics: drug and disease management (8. ed.) Philadelphia: Lippincott Williams and Wilkins (2006).

12. Lai C., et al. "Aetiology and Risk Factors of Acute Gastroenteritis in a Taipei Emergency Department: Clinical Features for Bacterial Gastroenteritis". Journal of Epidemiology 26.4 (2016): 216-223.

13. World Health Organisation (WHO). "Guidelines for Drinking Water Quality". 4th Ed. WHO press (2011): 564.

14. Clinical and Laboratory Standards Institute. Performance Standards for Antimicrobial Susceptibility Testing; TwentyThird Informational Supplement. CLSI document M100-S23. Clinical and Laboratory Standards Institute, 950 West Valley Road, Suite 2500, Wayne, Pennsylvania, 19087 USA (2014). 
15. Pandey K., et al. "Contamination of water resources by pathogenic bacteria”. AMB Express 4 (2014): 51.

16. Oluyemi EA., et al. "Physico-chemical Properties and heavy metal content of water sources in Ife North Local Government Area of Osun State, Nigeria". Africa Journal of Environmental Science and Technology 4 (2010): 691-697.

17. World Health Organization. The International Network to Promote Household Water Treatment and Safe Storage (2007).

18. Environmental Protection Agency (U.S. EPA). US Environmental Protection Agency Safe Drinking Water Act. EPA 816 - F - $03-016$ (2003).

19. Shittu OB., et al. "Physico-Chemical and Bacteriological Analysis of Water Used for Drinking and Swimming Purposes in Abeokuta, Nigeria". African Journal of Biomedical Research 11 (2008): 285-290.

20. Adejuwon JO and Adelakun MA. "Physiochemical and bacteriological analysis of surface water in Ewekoro Local Government Area of Ogun State, Nigeria: Case study of Lala, Yobo and Agodo Rivers". International Journal of Water Resources and Environmental Engineering 4.3 (2012): 66-72.

21. Adedeji OB and Onwenefah M. "The antibiotic resistant patterns of bacterial flora of cultured catfish fed with poultry hatchery waste from selected farms in Ibadan, Nigeria". Researcher 5.9 (2013): 37-43.

22. Maravić A., et al. "Aeromonas spp. simultaneously harbouring bla CTX-M-15, bla SHV-12, bla PER-1 and bla FOX-2, in wildgrowing Mediterranean mussel (Mytilus galloprovincialis) from Adriatic Sea, Croatia". International Journal of Food Microbiology 166 (2013): 301-308.

23. Harrigan RJ., et al. "New host and lineage diversity of avian haemosporidia in the northern Andes". Evolutionary Applications 7(2014): 799-811.

Volume 2 Issue 10 December 2019

(C) All rights are reserved by 0jo Omoyemi Rebecca and Olotu Emmanuel Juwon. 